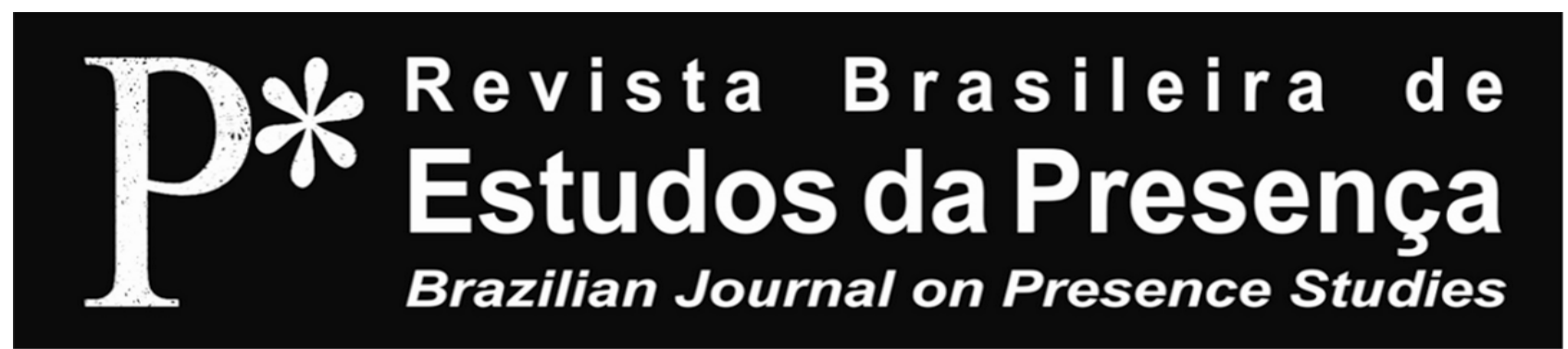

CONTEMPORARY TOPICS II

E-ISSN 2237-2660

\title{
Dance Theory as a Practice of Critique
}

\author{
Gabriele Klein' \\ 'Universität Hamburg - UHH, Hamburg/HH, Germany
}

ABSTRACT - Dance Theory as a Practice of Critique - Using dance as an example, the text discusses the questions of what aesthetic criticism means and how it manifests itself. Drawing on philosophical and social science positions on critique (Foucault, Butler, Bourdieu), he develops a practical-theoretical view of the practice of critique in contemporary dance.

Keywords: Critic. Aesthetics. Contemporary Dance. Practice. Dance Methodologies.

RÉSUMÉ - La Théorie de la Danse comme Pratique de la Critique - En s'appuyant sur l'exemple de la danse, cette contribution entend approfondir sur la question de quoi la critique esthétique est-elle le nom et quelles sont ses manifestations possibles? C'est à partir de positions acquises en philosophie et en sciences sociales à propos de la critique (Foucault, Butler, Bourdieu) que ce texte aborde une perspective pratico-théorique du processus critique en danse contemporaine.

Mots-clés: Critique. Esthétique. Danse contemporaine. Pratique. Méthodologies en danse.

RESUMO - Teoria da Dança como uma Prática de Crítica - Ao utilizar a dança como um exemplo, o texto discute a questão de como a crítica estética pode manifestar a si mesma, como também do significado que ela comporta. Ao basear-se no registro filosófico e nas ciências sociais, no que tange à noção de crítica (Michel Foucault, Judith Butler, Pierre Bourdieu), o presente estudo procura desenvolver uma perspectiva pratico-teórica do processo da crítica na dança contemporânea.

Palavras-chave: Crítica. Estética. Dança Contemporânea. Prática. Metodologias de Dança. 
Since the 1990s, the notion of dance and/or choreographic practice as critical practice has played a major role in dance studies. Pirkko Husemann's description of artistic methods of working as critical practice (Husemann, 2009), Susan Foster's theorem of embodied politics i.e. the politics of embodiment (Foster, 1996; 2002), Randy Martin's theory of mobilisation (Martin, 1998) or André Lepecki's topos of kinaesthetic politics (Lepecki, 2006) are all prime examples of this tendency.

All of these texts were written in the 1990s, like the artistic practices that they refer to - in other words in an age in which society radically began to change. Global society, unrestricted capitalism, the reputed end of class society, the end of the welfare state, neoliberal politics are the main keywords used to describe the changes that society is still going through and to explain the establishment of post-Fordian politics. These rapid and radical social transformations also seemed to herald in After Enlightenment (Klein; Naumann-Beyer, 1995) and The End of Criticism (Schödbauer; Vahland, 1997). Accordingly the end, the prefix post and the concepts of limitation and boundaries were central topics of cultural and social academic discourses in the 1990s.

These dance theories, which identify choreographic practice as being critical or political (or even occasionally use criticism and the political as synonyms), seem to stem themselves against the apocalyptic mood. They are not only paradigmatic for a contextualisation of the (in the academic and artistic context) still quite young field of dance theory as a critical theory or political philosophy of dance, but also - and closely associated therewith - for a turn towards artistic practice. On the one hand, this is due to the author's biographies. Many of these authors are themselves - as dramaturges, performers, dancers or choreographers - also practicing artists and have not, like many of an older generation, fully switched from artistic practice to theory. On the other hand, the relationship between theory and praxis in dance itself has also experienced a historical transformation over the last years due to changes in how dance, choreography and theory are taught and subsequently practiced: here the boundaries of dichotomous thinking have likewise become more fluid.

Dance theory, so the implicit and sometimes explicit assumption of these texts, can only be conceived as a theory of practice, as a theory, which does not exclusively or primarily concentrate on a product, but also - and 
foremost - on a process, i.e. by reflecting the methods used and the forms of collaboration. Dance theory is thus only conceivable in the context of a form of dance studies that defines itself as an empirical science (Erfahrungswissenschaft), as a science of reality, as a practical science. Dance theory, and this is the second premise, should be generated by the experience-guided reflection of artistic practice. Dance theory thus lies somewhere in-between, in a realm between artistic and scientific practices and their respective forms and methods of reflection. From this perspective, it is simultaneously the premise, instrument and effect of artistic practice.

Based on this realisation that dance theory formulates itself in and through dance or artistic practice, I would like to reverse the perspective by focusing on dance theory and asking how it can take place and define itself as critical practice. Therefore I would like to expound some fragmentary thoughts on the extensive subject of a praxeological critical theory of dance, i.e. a critical practice of thinking.

Two questions are of particular interest: How can we define critical practice in dance and choreography? And: What is the frame of reference for this critical practice?

\section{Dance and Choreography as Critical Practice}

In her dissertation, Pirkko Husemann analyses the working processes of French choreographer Xavier Le Roy and the German choreographer Thomas Lehmen. Her conclusion is that choreography is a critical practice. She defines it as "[...] practice immanent criticism in the mode of the aesthetic" (Husemann, 2009, p. 29), as criticism that is bound to artistic practice, especially to working methods and which therefore reveals itself via and through experience. Husemann shares this concept of a partial and immanent understanding of criticism with a handful of authors, who have, as dramaturges, emphasised the artistic process in particular as a modus operandi and realm of criticism.

In their argumentation, they are - implicitly - of the opinion, that critique cannot, contrary to the classical concept of critique as defined by Kant, be reduced to judgment alone. Instead they define critique as a mode of working that facilitates other experiences. Certain artistic methods of working are critical in the sense that they test new forms of community, 
friendship, and complicity, as well as experiment with new forms of production. These experimentally structured spaces of experience are also, in a different light, fields for experimenting with alternative social practices. Therefore, they also deal, so my main argument, with a different mode of socialisation, the communitarisation of subject formation. But:

\section{What does it mean to Exercise Practice-Immanent Critique?}

This question is, somewhat modified and expanded by the phrase practice-immanent, a question posed by Judith Butler in What is Critique? An Essay on Foucault's Virtue (Butler, 2002) in response to Foucault's What is Critique? (Foucault, 1997). Foucault's essay, which anticipated his probably more famous article What is Enlightenment? (Foucault, 1984), was motivated by the idea of finding a way out of the deadlock into which, in his opinion, critical and also post-critical theory had maneuvered itself. According to Butler (2002), he was attempting to rethink criticism as practice by questioning the limitations of accustomed forms of thinking. In principle, exercising what Horkheimer and Adorno called the critique of ideology in their reflections on Marx and their elaboration of Georg Lukács' concept of reification (Horkheimer; Adorno, 2002).

Butler emphasised three aspects, which I regard as important in the debate on choreographic modes of working as critical practice: the concept of practice, the realm of critique and its framework. She writes: "Critique is always a critique of some instituted practice, discourse, episteme, institution, and it loses its character the moment in which it is abstracted from its operation and made to stand alone as a purely generalizable practice" (Butler, 2002, p. 212). The practice of critique is thus always particular, although it is also generalizable, i.e. it always refers to a concrete context, but allows conclusions to be drawn that apply other realms and frameworks.

Although, Plato defined critique as the skill or technique of differentiation required in order to be able to pass judgement, Butler and Foucault nevertheless insist that critique is actually far more and something other than judgement. However, it would be historically oversimplified to claim this to be a genuine position of post-structural thought. As Kant stated in his demarcation of critique from the medieval monopoly of exegesis: "The critical method suspends judgment" (Kant, 1969, p. 459). But in the case 
of Kant, suspension takes place with the goal of reaching a verdict. In the case of Butler and Foucault, there is utter suspension, because critique is a practice that can only generate a new ethical practice based on that very suspension. In this respect, they are also in agreement with authors of critical enlightenment such as Raymond Williams or Adorno. Adorno, for example, demanded: "[...] when cultural criticism appeals to a collection of ideas on display, as it were, and fetishizes isolated categories" (Adorno, 1983 , p. 23), it must reflect "[...] the ways in which categories are themselves instituted, how the field of knowledge is ordered, and how what it suppresses returns, as it were, as its own constitutive occlusion" (Butler, 2002 , p. 213). In contrast to judgement, which takes place within constituted categories (e.g. in the categories classical, modern, contemporary), critique directly deals with how a field is constituted, to paraphrase Pierre Bourdieu, e.g. the field of contemporary dance and its historical epistemes and respective dispositifs. Critical practice is thus a practice that questions those principles of constitutions and figures of thought, which themselves determine the field. It questions the respective knowledge generated there and reveals the mechanisms behind practices of inclusion and exclusion. Critical practice is thus always also a practice of experiencing liminality, both epistemologically and ontologically. These definitions of critical practice apply both to artistic, as well as academic practice. Butler (2002, p. 215) says:

One does not drive to the limits for a thrill experience, or because limits are dangerous and sexy, or because it brings us into a titillating proximity with evil. One asks about the limits of ways of knowing because one has already run up against a crisis within the epistemological field in which one lives.

The crisis of the epistemological field of dance in modernity began with the so-called cultural crisis around the turn of $20^{\text {th }}$ century. The history of dance can since boast of a number of epistemological disruptions and fractures, such as those inflicted e.g. by American postmodern dance in the 1960 s (e.g. the use of non-places of dance, the integration of non-dancers, the performance of everyday movements and gestures) or in the 1970s by Tanztheater (dance theatre) (e.g. by focusing on the dancer himself/herself as the embodiment of knowledge, establishing the role of dramaturges in dance and emphasizing the processual character of choreography, Pina Bausch not only developed a new aesthetic and compositional structure, but 
also challenged the epistemological stability of the dance field) (cf. Lepecki, 2006). To say nothing of the influences of popular dances, which have opened up the field of dance to the realm of the everyday in very different ways than contemporary dance - thus producing a new crisis of its own. The critical practice has since always been locked into a landscape defined by the crisis of the epistemological field. And this landscape of crisis is contingent. According to Niklas Luhmann, contingency is something that excludes

[...] necessity and impossibility. Something is contingent insofar as it is neither necessary nor impossible; it is just what it is (or was or will be), though it could also be otherwise. The concept thus describes something given (something experienced, expected, remembered, fantasised) in the light of its possibly being otherwise; it describes objects within the horizon of possible variations (Luhmann, 1996, p. 106).

To be, in principle, open for the future also means, that - contrary to the occasionally observable historical amnesia of dance theory and dance practice - critique's frame of reference must also always be historical. It must reflect respective current structures of thinking, forms of knowledge and cognition against the historical backdrop of the epistemological crisis of dance, which is in turn related to the social order that I will refer to in more detail later on. From this perspective of historical reflection, I would like to state the following: The critical moment in current artistic practices is particular, can only be identified in its concrete form and must always be regarded in relationship to historical predecessors. How do current choreographic practices relate e.g. to modes of working - taking into account only West German dance history - such as Gerhard Bohner's collective methods of working in Darmstadt end of the 1960s or to the disruptions of dance history caused by Pina Bausch's mode of working? How is critical practice possible today in the contingent unstable space that dance is situated in since the 1960s? This question brings us to the concept of practice itself.

\section{What does the Term Practice Mean?}

In various discussions of theory and praxis, the term practice is sometimes used colloquially. In such cases, practice means artistic creation and is generally considered to be praxis, that which comes first, theory being the other. Or the debate cites the tradition of a philosophy of praxis, based on the 
early writings of Karl Marx (Marx, 2004 [1844]; Marx; Engels, 1969 [1845]). Marx defines praxis as the sensual or concrete activity of mankind, as a subjective, material transformation of objective reality, which involves productive, political, experimental, artistic, and other material acts. Praxis is thus established as the criterion of reality versus theory.

In contrast, we have a theory of practice, which first came up in the $20^{\text {th }}$ century in form of a social-theoretical approach. In other words, it questions the dual construction theory and praxis that is historically often discussed in dance as the binarity of body and mind. This concept of critique moreover distances itself from dualism-based notions that favour praxis over theory by arguing that artistic practice is the real and thus privileged place of critique. If we follow the dualistic line of thought, it is very difficult to regard artistic practice as being capable of critique. Dualism itself moves within established epistemes, within fixed forms of thinking, knowledge and action, which on the one hand, establish theory as an act of reaching a verdict and praxis as the site of experience and on the other hand, stipulate the concept of practice as an essential or ontological category. Practice therefore would solely be allocated to the field of dance and theory would be located outside this field.

From a sociological perspective, especially from the perspective of Bourdieu's praxeology, this use of language not only signifies a confusion of the term practice with that of the term field. Such a use of terminology, also favours essentialism and neglects to take into account the fact that practice is a constructivist term, which describes processes of subjectification, is oriented on materialities, i.e. bodies and objects and situates the social in the actual practices themselves (Reckwitz 2003). Theory of practice defines collective knowledge not as knowing that but rather as knowing how, i.e. as an ensemble of techniques, as practical comprehension, as being skilled at. And this knowledge is, again paraphrasing Bourdieu, incorporated: it is mimetically and performatively produced by concrete, specific practices. Practice is here thus meant less as an emphatic totality, but rather as an accumulation of procedures that follow a logic of practices and are connected by practical skill. And this is always tied to two material instances: to the body and the artifacts. Be it practices of organisation, of friendship, of artistic creation, of reading and writing, of handling the body or tools - from this perspective, practices must always be '[...] understood as the 'skillful performance' of 
competent bodies" (Reckwitz, 2003, p. 290) ${ }^{1}$, even when they involve intellectual practices.

Practices constitute subjects. If we follow Foucault, practice is a pool of techniques and arts for the formation of the self and this always takes place in relationship to a field, for example to the field of dance and its subfields of artistic or popular dance, of modern, contemporary or postmodern dance, etc. and their rules, norms, conventions and orders. In other words: practice is the respective field-immanent modus operandi of the socialisation of the subject revealing itself in routine practices. This formation of the subject cannot simply be understood as an introduction into social structures via socialisation. It always also entails desubjugation (Foucault) or desurrender. This is, according to Foucault, the case, when the practice of self-formation takes place as critical practice. From the perspective of selfcultivation, critical practice can never be described as something general or even uniform. It only exists in a particular relationship to something other than itself.

From this perspective of a theory of practice, practice should not be differentiated from theory, but instead regarded as a collective term for the techniques and practices prevalent in the field of dance - and its subfields. They are produced in those working methods and forms of collaborating and producing knowledge, by which dancers turn themselves into dancers, choreographers into choreographers, theorists into theorists, etc.

\section{How can Practice thus Articulate itself as Critical Practice?}

Foucault has a clear answer to this question:

Critique doesn't have to be the premise of a deduction which concludes: this then is what needs to be done. It should be an instrument for those who fight, those who resist and refuse what is. Its use should be in processes of conflict and confrontation, essays in refusal. It doesn't have to lay down the law for the law. It isn't a stage in a programming. It is a challenge directed to what is (Foucault, 2000, p. 236).

For Foucault, critique is "[...] the art of voluntary subordination, that of reflected intractability" (Foucault, 1997, p. 47). It is not by coincidence that Foucault here uses the term art. For him, the practice of critique is based on a way of life, on what he has famously called the "[...] art of existence" (Foucault, 1990, p. 10). For Foucault, this art of existence takes place 
in the modus operandi of the aesthetic and the ethical, because for him, critique is also a virtue. It produces techniques of the self by which men seek "[...] to transform themselves, to change themselves in their singular being and to make their life into an oeuvre that carries certain aesthetic values and meets certain stylistic criteria" (Foucault, 1990, p. 10).

Critique itself is an art that reveals the limitations of the epistemological field and sets itself in relation to this limitation. Critical practice in the field of dance is accordingly that which refuses to adhere to a category - in terms of: theory here, practice there, knowledge here, experience there, etc., "[...] but rather constitute an interrogatory relation to the field of categorization itself, referring at least implicitly to the limits of the epistemological horizon within which practices are formed" (Butler, 2002, p. 217).

It focuses on the relationship between the limitations of ontology and epistemology, i.e. the limits "[...] of what I might become and the limits of what I might risk knowing" (Butler, 2002, p. 217). Critical practice thus always also means risking the definition of oneself as a subject, as dancer, theorist, choreographer, etc. and assuming an ontologically precarious, risky and crisis-laden position.

This position requires a degree of reflexivity, which cannot only be described in terms of critical theory as defined by the Frankfurt School, but must also be seen as an objectified reflexivity (Bourdieu, 1993; Bourdieu; Wacquant, 1992); in other words, not only reflecting one's own point of view, but also the immanent limitations of the field of art. We are trapped in our field (Fraser apud Raunig, 2006), says artist Andrea Fraser. In the case of art criticism, formulating critique in terms of limitations thus also means, as Jens Kastner (2010, p. 127) has written, "[...] to reject the phantasm of captivity as restricting self-description and to insist on never thinking about critique without also taking into consideration social battles". Social battles here first and foremost mean the exemption of art from politics and the declaration of art as an autonomous field - thus radically questioning its a priori synthesis as a community of critique. For with this separation, as Iris Därmann (2008, p. 32) has convincingly illustrated "[...] community becomes a mere concept and fantasy that has revoked its connection to conflict and the political and ceded the rules of distribution and division to the law and the state"2. This is exactly where Därmann sees the policy-making character of political philosophy: when it doesn't infringe on these inequali- 
ties and by doing so suppresses the political, "[...] i.e. that power of the ensemble of cultural practices to establish sociality, which produces the separate coexistence of a singular that no form of politics is capable of producing” (Därmann, 2008, p. 36) .

\section{What is the Framework of Critical Practice?}

In her dissertation, Pirkko Husemann emphasised that practiceimmanent critique in dance can only be recognised as critical practice when distinguishable not only as an aesthetic, but as a social practice (Husemann, 2009, p. 61). However, it would be overly simplified - and also somewhat outdated - to define the social merely as a general framework for the aesthetic. Various authors - from Bourdieu to Rancière - have pointed out the inseparability of the aesthetic i.e. aisthetic from the social or rather political. The social, so a basic assumption of performative concepts in the wake of Bourdieu, can only be experienced as sensuous, embodied, habitualised practice. It reveals itself even in modus operandi of the aesthetic, i.e. in the way it is produced, perceived and experienced.

If the social and the aesthetic are so inseparably related in the moment of experience, what can and must immanent critical practice in dance and choreography refer to in order to be political?

This question is very complicated, when taking into consideration that not every critical practice is inevitably political and vice versa. The political is not necessarily critical. If we stick to political theory, the political is always related to politics, which can in turn be defined as the practice of institutionalizing social norms. The political can be seen as the vanishing point of politics. Take away the connection and the political is unrecognizable. From the perspective of critical social theory, critique can only then be conceived as political, when it formulates itself as social criticism, i.e. references the institutionalisation of social norms.

Various post-Marxist theorists such as Lefort (1990), Laclau and Mouffe (1985), Balibar (2010), Rancière (2007), Badiou (2013) or Hardt and Negri (2001) and in their wake, Virno (2004), have addressed this identification of the political with social criticism. Unlike liberal, communitarian or deliberative political concepts, they emphasise the constitutive schism of the social. This forms the premise for determining the place of 
the political. For them, it manifests itself reactively, as well as situational in the mode of action and here in the articulation of dissent, of disruption, of the incident. The distinct and not the shared is the site of the political and it contains the possibilities for a political practice of critique. For while assertions of the shared lead to hegemonic categories and a closed concept of community, which unquestioningly assumes a group us that is capable of action, the distinct is the only space that really provides opportunity for critique and a sense of common-unity. And this, if we follow the arguments of post-Marxist authors, finds its expression in a practice of disordering, disordinance. It destabilizes, irritates and dis-places an existing order.

In doing so, it is not so much circumvention, a subversive strategy against a stable order, as e.g. André Lepecki has hinted at in his theory, which defines movement as kinaesthetic politics against the order of the kinetic - thereby positing the relationship of order and movement as that of microstructure and macrostructure (Lepecki, 2006). Instead, the political expresses itself in the irresolvable potential for conflict that is contained in the social and stored in its schism. It is not the against or the outside, the independent against the institution, praxis against theory, movement against choreography, which can be identified as the (normative) site of the political against instituted politics. The practice of the political instead means placing oneself in relation to the hegemonic character of a social system and grasping it, as Chantal Mouffe (2008, p. 4) writes "[...] as the product of a series of practices whose aim is to establish order in a context of contingency". For Mouffe (2008, p. 4) "[...] every order is the temporary and precarious articulation of contingent practices".

As a framework for critique, social order - and social order also means forms of incorporating these orders, such as e.g. the order of ballet or other dance epistemes - can thus be conceived as an emerging order as defined by Luhmann, i.e. as a fluctuating, temporary, even performatively produced order, whose genesis cannot ultimately be reconstructed. It is always shaped by the inclusion and exclusion of other options and by power relations that are always specific. It is an order that is contingent and whose articulation is preceded by confrontation, whose outcome is not predetermined.

The idea that systems can be thought about as emergent and performative is by no means new and was already expressed in the 1930s by Norbert Elias in his theory of figuration sociology (Elias, 1978). One vivid 
conceptual example for emergent choreographic orders, which are always precarious and contingent, can be found e.g. in works made by William Forsythe and Dana Caspersen. One example of these choreographic objects is the installation White Bouncy Castle (1997) commissioned by Artangel, London. "The White Bouncy Castle transfers the various states of physicalspatial organization, which choreography is concerned with, into a state of autonomy, which requires no further channeling influence [...]", says Forsythe (apud Rietz 2010, s. p.). If we define participation as the act of taking part, the audience is active, but moves beyond the mere framework of a conceptual pre-scription. Instead, the audience takes an active role in performatively shaping the choreographic structure through corporeal practice within the framework of the material provided. White Bouncy Castle is a project that questions the concept of choreography, the substance of art and the artistic space itself in and through the participation of all persons involved. By moving around in the 30x11 meter Bouncy Castle, the visitors produce a choreographic order of the ephemeral, which is unique in every one of its moments and cannot be repeated. A community is produced that is open, unpresuming in its identity and continuously redefining its we. The White Bouncy Castle is a political project in the sense that it symbolizes a practical critique of the order of choreography as a firmly established system, conceived by one person and implemented by specialists. It is political, because it applies a model of democracy that in principle allows anyone to take part. And it is simultaneously related to politics in as much as that it is nevertheless marked by principles of inclusion and exclusion - not everyone has access to the art-space in which the White Bouncy Castle stands and not all visitors take part, some preferring to watch or to only participate in a certain way. The power balances created when jumping, the order of configuration is performative and situational, but as a structure of power, it is necessary in order to be able to create movement at all.

\section{What could be a Place of Critique?}

In a study based on Max Weber's The Protestant Ethic and the Spirit of Capitalism (Weber, 2001) and the theories of Bourdieu and Robert Castel, Luc Boltanski and Ève Chaipello (Boltanski; Chaipello, 2007) have demonstrated that the driving force behind the tranformations, which the new spirit of capitalism has undergone, has been a critique of capitalism as for- 
mulated by specific social groups. A particularly impelling moment of change came from what they call artist critique. They demonstrate that artists' lifestyles have been especially decisive in establishing a new spirit of capitalism. This new spirit of capitalism rejects all institutions and forms of the social that draw up and seek to retain boundaries. Instead, it is based on a concept of a world that exists as the Net, as a Project. Words such as teamwork, vision, competency, flexibility, innovation, self-organisation, immaterial work, (re)production of affects best represent this idea.

A similar problem of the affirmation is evident in choreographic practice (Klein, 2009). The structures of post-Fordism demand creative, flexible human beings, communicative, cooperative and affective forms of working, as well as intellectual, immaterial work. How can radical dissent and intervention take place in artistic practice, if these same artistic strategies and ways of life are appropriated by neoliberal politics as proto-types and as feedback to optimize the system? How can the artist/theorist subject transform itself, when the aesthetic modus operandi of self-formation, as Foucault demonstrated, is framed by ethic practices, which in turn require a political context i.e. normative politics? And finally, how can the artist/theorist subject transform itself, when this very act of transformation is, although accomplished by the subject himself/herself, nevertheless confined to a framework of subjectification practices, which are de facto submitting to neoliberal positions?

These questions are not only relevant for artistic practice, but also for the practice of dance theory: how can critical theory be possible as critical practice when standardisation, de-intellectualisation, constant re-evaluation and the fabrication of conceptual consensus, which manifests itself in rankings, provoke particular forms of thinking and practices?

If the political is understood as a practice of social criticism, which "[...] changes the very framework that determines how things work" (Zizek, 2000, p. 199), then the political - especially in the academic field - has become rare or even impossible in the context of new forms of a hegemonic order (of knowledge). Dance theory, understood as a practice of critique, is those required, on the one hand, to operate along the immanent borderlines of the epistemological field of dance and, on the other, to take the risk of entering the space of crisis in the institutions. "A properly political intervention is always one that engages with a certain aspect of the existing he- 
gemony in order to disarticulate/re-articulate its constitutive elements" (Mouffe, 2008, p. 6). Dance theory is a practice that can and must operate out of a large number of places. It should not however form itself outside of institutions, but instead intervene in them from various standpoints with the goal of changing them. We should seek to develop "[...] a riskier practice that seeks to yield artistry from (the) constraint(s) [...]" of the institutions and develop forms of "[...] the practical theorist/theoretical practitioner" (Butler, 2002, p. 226), which (can) create dissent versus the politics of (knowledge) institutions. This task could also be part of the critical practice encouraged in the many academic BA and MA-courses that have recently sprung up in Germany for dance, performance and choreography. According to the trains of thought followed above, this too could be part of a practice of critique spawning a critical dance theory of practice.

\section{Notes}

1 Translated by Elena Polzer.

2 Translated by Elena Polzer.

3 Translated by Elena Polzer.

\section{References}

ADORNO, Theodor W. Cultural Criticism and Society. In: ADORNO, Theodor W. Prisms. Translated by Samuel and Shierry Weber. Cambridge, MA: MIT Press, 1983. P. 17-34.

BADIOU, Alain. Das Erwachen der Geschichte. Translated by Richard SteurerBoulard. Wien: Passagen, 2013.

BALIBAR, Étienne. La Proposition de l'Égaliberté: essais politique, 1989-2009. Presses Universitaires France: Paris 2010.

BOLTANSKI, Luc; CHAIPELLO, Ève. The New Spirit of Capitalism. London: Verso, 2007.

BOURDIEU, Pierre. Narzisstische Reflexivität und wissenschaftliche Reflexivität. In: EBERHARD, Berg; MARTIN, Fuchs (ed.). Kultur, soziale Praxis, Text: Die Krise der ethnografischen Repräsentation. Frankfurt am Main: Campus, 1993. P. 365-374. 
BOURDIEU, Pierre; WACQUANT, Loic. An Invitation to Reflexive Sociology. Chicago, Ill; Cambridge, UK: University of Chicago Press; Polity Press, 1992.

BUTLER, Judith. What is Critique? An Essay on Foucault's Virtue. In: INGRAM, David (ed.). The Political: Readings in Continental Philosophy. London: Basil Blackwell, 2002. P. 212-226.

DÄRMANN, Iris. Figuren des Politischen. Frankfurt am Main: Suhrkamp 2008.

ELIAS, Norbert. What Is Sociology?, Columbia University Press, 1978.

FOSTER, Susan Leigh. Corporealities, Dancing, Knowledge, Culture and Power. London: Routledge, 1996.

FOSTER, Susan Leigh. Dances That Describe Themselves. Middleton: Wesleyan University Press, 2002.

FOUCAULT, Michel. What is Enlightenment? In: RABINOW, Paul (ed.). The Foucault Reader. New York: Pantheon Books, 1984. P. 32-50. Available at: <http://foucault.info/documents/whatIsEnlightenment/foucault.whatIsEnlightenment.en.html>. Accessed on: July 19, 2012.

FOUCAULT, Michel. The Use of Pleasure: The History of Sexuality (Volume 2). New York: Vintage Books, 1990.

FOUCAULT, Michel. What is Critique?. In: LOTRINGER, Sylvère; HOCHROTH, Lysa (ed.). The Politics of Truth. New York: Semiotext(e), 1997. P. 41-81.

FOUCAULT, Michel. The Essential Foucault: Selections from Essential Works of Foucault, 1954-1984. New York: New Press, 2000.

HARDT, Michael; NEGRI, Antonio. Empire. Cambridge, Mass: Harvard University Press, 2001.

HORKHEIMER, Max; ADORNO, Theodor W. Dialectic of Enlightenment. Translated by Edmund Jephcott. Stanford: Stanford University Press, 2002.

HUSEMANN, Pirkko. Choreographie als kritische Praxis. Bielefeld: transcript, 2009.

KANT, Immanuel. Kants gesammelte Schriften, Handschriftlicher Nachlass, Logik (Akademie-Ausgabe): volume 16. Berlin: de Gruyter, 1969.

KASTNER, Jens. Zur Kritik der Kritik der Kunstkritik. Feld- und hegemonietheoretische Einwände. In: NOWOTNY, Stefan; RAUNIG, Gerald; 
MENNEL, Birgit (ed.). Kunst der Kritik. Vienna: Turia und Kant, 2010. P. 125-147.

KLEIN, Gabriele. Das Flüchtige: Politische Aspekte einer tanztheoretischen Figur. In: HUSCHKA, Sabine (ed.). Wissenskultur Tanz. Bielefeld: transcript, 2009. P. 199-209.

KLEIN, Wolfgang; NAUMANN-BEYER, Waltraud (ed.). Nach der Aufklärung? Beiträge zum Diskurs der Kulturwissenschaften. Berlin: Akademie, 1995.

LACLAU, Ernesto; MOUFFE, Chantal. Hegemony and Socialist Strategy: towards a radical democratic politics. London: Verso, 1985.

LEFORT, Claude. Die Frage der Demokratie. In: RÖDEL, Ulrich (ed.). Autonome Gesellschaft und libertäre Demokratie. Frankfurt a. M.: Suhrkamp, 1990. P. 281-297.

LEPECKI, André. Exhausting Dance: performance and the politics of movement. New York: Routledge, 2006.

LUHMANN, Niklas. Social Systems. Stanford: University Press, 1996.

MARTIN, Randy. Critical Moves: dance studies in theory and politics. Durham: Duke University Press, 1998.

MARX, Karl. Economic and Philosophical Manuscripts (1844). In: FROMM, Erich (ed.). Marx’s Concepts of Man. London: Continuum, 2004. P. 78-132.

MARX, Karl; ENGELS, Friedrich. The German Ideology (1845). New York: International Pub, 1969.

MOUFFE, Chantal. Critique as Counter-Hegemonic Intervention. Transversal, Vienna, v. 4, 2008. Available at: <http://eipcp.net/transversal/0808/mouffe/en>. Accessed on: July 19 $19^{\text {th }}, 2012$.

RANCIÈRE, Jacques. Hatred of Democracy. Translated by Steve Corcoran. London; New York: Verso, 2007.

RAUNIG, Gerald. Instituent Practices: Fleeing, Instituting, Transforming. Transversal, Vienna, v. 1, 2006. Available at: <http:/eipcp.net/transversal/0106/rau-nig/en>. Accessed on: July 19 ${ }^{\text {th }}, 2012$.

RECKWITZ, Andreas. Grundelemente einer Theorie sozialer Praktiken. Zeitschrift für Soziologie, Bielefeld, n. 4, p. 282-301, 2003. 
RIETZ, Christina. Hüpfen als Kunstform. Zeit Online, Hamburg, August 16, 2010. Available at: <http://www.zeit.de/lebensart/2010-08/huepfendeichtorhallen>. Accessed on: July 19 $9^{\text {th }}, 2012$.

SCHÖDBAUER, Ulrich; VAHLAND, Joachim. Das Ende der Kritik. Berlin: Akademie-Verlag, 1997.

VIRNO, Paul. A Grammar of the Multitude: for an analysis of contemporary forms of life. New York: Semiotext[e], 2004.

WEBER, Max. The Protestant Ethic and the Spirit of Capitalism. London: Routledge, 2001.

ZIZEK, Slavoj. The Ticklish Subject: the absent centre of political ontology. London: Verso, 2000.

Gabriele Klein is professor for dance and performance studies at Hamburg University. She is director of the center for performance studies Hamburg and PI of the excellence cluster Understanding. Written artefacts. Her English book publications include: Emerging Bodies (with S. Noeth), Dance (and) Theory (with G. Brandstetter), Performance and Labour (with B. Kunst), Pina Bausch's Dance Theater. Company, Artistic Practices, and Reception.

ORCID: https://orcid.org/0000-0001-9089-8501

E-mail: gabriele.klein@uni-hamburg.de

This English version has already been published in: KLEIN, Gabriele. Dance Theory as a Practice of Critique. In: BRANDSTETTER, Gabriele; KLEIN, Gabriele (ed.). Dance (and) Theory. Bielefeld: transcript 2013. P. 137-149.

Received on May 18, 2020

Accepted on July 29, 2020

Editor-in-charge: Marcelo de Andrade Pereira

This is an open-access article distributed under the terms of the Creative Commons Attribution License 4.0 International. Available at: <http://creativecom mons.org/licenses/by/4.0>. 